\title{
YLIOPISTOKIRJASTOT JA LEIDENIN MANIFESTI
}

Kirjastojen tulisi edistää vastuullista bibliometriikkaa. Leidenin manifesti vuodelta 2015 antaa suosituksia bibliometriikan vastuulliseen käyttöön tutkimuksen arvioinnissa. Kuinka hyvin manifestin periaatteet istuvat yliopistokirjastojen käytäntöihin? Millaisia suosituksia LIBERin metriikkatyöryhmä antaa manifestin käytöstä?

Keväällä 20 5 Diana Hicks, Paul Wouters, Ludo Waltman, Sarah de Rijcke ja Ismael Rafols julkaisivat kirjoittamansa Leidenin tutkimusmetriikkamanifestin Nature-lehdessä. Siinä kirjoittajat määrittelevät itsensä tutkimusmetriikan asiantuntijoiksi, yhteiskuntatieteilijöiksi ja tutkimushallinnon edustajiksi. Manifestin nimi tulee siitä, että kirjoittajat aloittivat sen tekemisen hollantilaisessa Leidenin kaupungissa vuonna 20I 4 pidetyssä Science, Technology, and Innovation Indicators -konferenssissa.

eidenin tutkimusmetriikkamanifesti on käännetty I9 kielelle (käännökset verkossa: http:// www.leidenmanifesto.org/translations. html). Se käännettiin suomeksi ja ruotsiksi Suomen yliopistokirjastojen neuvoston tutkimuksen tuen verkoston ohjausryhmän toimesta joulukuussa 2016.

Leidenin manifesti esittää kymmenen periaatetta, jotka manifestin laa- tineen asiantuntijaryhmän mukaan pitäisi ottaa huomioon tutkimuksen arvioinnissa. (Ks. taulukko 2.)

\section{LIBERin metriikkatyöryhmän analyysi ja suositukset manifestista}

LIBERin metriikkatyöryhmä (LIBER Working Group on Metrics) arvioi kesällä 20I7 Leidenin manifestia erityisesti tieteellisten kirjastojen metriikkapalvelujen kehittämisen näkökulmasta.

LIBERin ryhmän tarkastelu on bibliometriikkaa laajempi, metriikan näkökulma. Tämä on luontevaa, sillä työryhmässä on mukana mm. suomalainen altmetriikan tutkija Kim Holmberg. Metriikkatyöryhmä toteaa, että Leidenin manifestin vaikutukset näkyvät jo käytännössä: esimerkiksi brittiläinen Loughboroughn yliopisto on sisällyttänyt Leidenin manifestin osaksi "building excellence" -strategiaansa. (Coombs \& Peters 2017, 325.) 
LIBERin ryhmän näkemys on, että kirjastojen näkökulmasta manifestin täydellinen noudattaminen ei ole mahdollista resurssisyistä, mutta sen periaatteiden tunteminen on tärkeää erityisesti kirjastojen osaamisen kehittämisen kannalta.

Coombs ja Peters (2017) korostavat, että Leidenin manifestissa, kuten muissakin vastaavissa suosituksissa, nousevat esiin mm. seuraavat suositellut toimintatavat:

Märärälinen analyysi täydentää laadullista analyysiä

Taustalla oleva data ja menetelmät on kuvattava

- Arvioinnin tarkoituksen, indikaattorien valinnan ja arvioitavan tieteenalan on oltava linjassa keskenään

- Datan ja menetelmien rajoitukset on kerrottava

Dataa, indikaattoreita ja menetelmiä on arvioitava ja kehitettävä

säännöllisesti (Pickton 2015; tässä Coombs \& Peters 2017, 325).

Olennaisen tärkeiksi tieteellisille kirjastoille Coombs ja Peters näkevät periaatteet yksi ja neljä. Hyvin tärkeiksi

he luokittelevat periaatteet viisi - kuusi ja kahdeksan - kymmenen. Tärkeiksi nähdään myös periaatteet kaksi ja kolme. Sen sijaan periaate seitsemän ei ole tärkeä kirjastoille, mutta hyvin tärkeä tutkijoille, hallinnolle ja julkaisurekisterin omistajille - joka voi toki olla, ainakin osittain, kirjasto.

Taulukko 1: Periaatteiden tärkeysjärjestys tieteellisille kirjastoille (Coombs \& Peters 2017, 327-335)

\begin{tabular}{c|c|c|c} 
Olennaisen tärkeä & Hyvin tärkeä & Tärkeä & Ei tärkeä \\
\hline 1,4 & $5-6,8-10$ & $2-3$ & 7
\end{tabular}

Taulukko 2: Leidenin manifestin periaatteet ja Coombsin ja Petersin (2017) analyysi Leidenin manifestista. Leidenin manifestin käännös, ks. Hicks et al. 2016

\begin{tabular}{|c|c|c|c|}
\hline $\begin{array}{c}\text { Leidenin } \\
\text { manifestin } \\
\text { periaate } \\
\text { (Hicks et al. 2015) }\end{array}$ & $\begin{array}{c}\text { Periaatteiden } \\
\text { sisältö } \\
\text { (Hicks et al. 2015) }\end{array}$ & $\begin{array}{l}\text { Käyttökelpoisuus } \\
\text { tieteellisissä } \\
\text { kirjastoissa } \\
\text { (Coombs \& Peters } \\
\text { 2017) }\end{array}$ & $\begin{array}{c}\text { Kommentteja ja } \\
\text { suosituksia tieteellisille } \\
\text { kirjastoille }\end{array}$ \\
\hline $\begin{array}{l}\text { 1. Määrällisen } \\
\text { arvioinnin pitäisi } \\
\text { tukea laadullista } \\
\text { asiantuntija- } \\
\text { arviointia. }\end{array}$ & $\begin{array}{l}\text { Määrällinen arviointi } \\
\text { ei riitä, tarvitaan laa- } \\
\text { dullista tarkastelua, } \\
\text { vertaisarviointia. }\end{array}$ & $\begin{array}{l}\text { Olennaisen tärkeä } \\
\text { kaikille kirjastoille } \\
\text { riippumatta metriikka- } \\
\text { palvelujen kehitysvai- } \\
\text { heesta } \\
\text { Priorisointi: korkea. }\end{array}$ & $\begin{array}{l}\text { Kirjaston työntekijöiden } \\
\text { osaamista tutkimuksen } \\
\text { määrällisestä että laadul- } \\
\text { lisesta arvioinnista tulee } \\
\text { kasvattaa. } \\
\text { Kansallinen ja kansainväli- } \\
\text { nen yhteeistyö tärkeitä. } \\
\text { Laadullinen arviointi vie } \\
\text { aikaa ja on kallista. }\end{array}$ \\
\hline $\begin{array}{l}\text { 2. Tarkastele } \\
\text { suoritusta } \\
\text { suhteessa } \\
\text { instituution, } \\
\text { ryhmän tai } \\
\text { tutkijan omaan } \\
\text { tutkimusmissioon. }\end{array}$ & $\begin{array}{l}\text { Tutkimuksilla on eri- } \\
\text { laisia tavoitteita ja } \\
\text { tarvitaan erilaisia ar- } \\
\text { viointimalleja. }\end{array}$ & $\begin{array}{l}\text { Tärkeä kirjastoille, } \\
\text { otettava huomioon } \\
\text { käyttäjäkeskeisiä pal- } \\
\text { veluita kehittäessä. } \\
\text { Priorisointi: matala. }\end{array}$ & $\begin{array}{l}\text { Kirjaston tulisi pyrkiä } \\
\text { olemaan mukana tutki- } \\
\text { muksen arvioinnin suunnit- } \\
\text { telussa. } \\
\text { Arvioinnin tavoite on usein } \\
\text { epäselvä, liian yleinen tai } \\
\text { sitä ei ole lainkaan ase- } \\
\text { tettu. }\end{array}$ \\
\hline $\begin{array}{l}\text { 3. Ota huomioon, } \\
\text { että paikallisesti } \\
\text { merkittävä } \\
\text { tutkimus voi olla } \\
\text { huippututkimusta. }\end{array}$ & $\begin{array}{l}\text { Kaikki kansallinen } \\
\text { erityisosaaminen ei } \\
\text { näy englanninkieli- } \\
\text { sissä lehdissä, joissa } \\
\text { julkaisemista arvoste- } \\
\text { taan. Tulisi rakentaa } \\
\text { metriikkaa, joka tun- } \\
\text { nistaa paikallisen tut- } \\
\text { kimuksen tärkeyden. }\end{array}$ & $\begin{array}{l}\text { Tärkeä niille kirjastoil- } \\
\text { le, jotka palvelevat } \\
\text { humanistis-yhteiskun- } \\
\text { nallisia tieteenaloja. } \\
\text { Muille melko tärkeä. } \\
\text { Priorisointi: keskiverto. }\end{array}$ & $\begin{array}{l}\text { Kirjasto voisi käyttää pai- } \\
\text { kallista julkaisuarkistoa } \\
\text { tai julkaisurekisteriä mah- } \\
\text { dollistaakseen vertailun } \\
\text { samantyylisiin laitoksiin } \\
\text { tutkijoiden itsearvioinnissa. } \\
\text { Tieteenalakohtaisten tai } \\
\text { kansallisten tietokantojen } \\
\text { rakentaminen voisi toimia } \\
\text { vaihtoehtona lisensioiduille } \\
\text { aineistoille, antaa mahdol- } \\
\text { lisuuden benchmarking- } \\
\text { toimintaan. }\end{array}$ \\
\hline $\begin{array}{l}\text { 4. Huolehdi, } \\
\text { että aineiston } \\
\text { kerääminen ja } \\
\text { analyysiprosessit } \\
\text { ovat avoimia, } \\
\text { läpinäkyviä ja } \\
\text { yksinkertaisia. }\end{array}$ & $\begin{array}{l}\text { Mittarien tulee olla } \\
\text { yksinkertaisia, perus- } \\
\text { teltavissa ja kaikkien } \\
\text { tiedossa, mutta met- } \\
\text { riikka ei saa olla yk- } \\
\text { sinkertaistavaa. }\end{array}$ & $\begin{array}{l}\text { Olennaisen tärkeä kai- } \\
\text { kille kirjastoille, kun } \\
\text { kehitetään prosesseja } \\
\text { ja palveluita. }\end{array}$ & $\begin{array}{l}\text { Onnistumisen aste riippuu } \\
\text { toimeksiannosta ja paikal- } \\
\text { lisesta tilanteesta. } \\
\text { Avoimuus, läpinäkyvyys ja } \\
\text { yksinkertaisuus tulisi mää- } \\
\text { ritellä selkeämmin. } \\
\text { Muiden tuottamat mitta- } \\
\text { rit ja metriikka ovat usein } \\
\text { monimutkaisia. }\end{array}$ \\
\hline $\begin{array}{l}\text { 5. Anna } \\
\text { arvioitaville } \\
\text { mahdollisuus } \\
\text { tarkistaa data ja } \\
\text { analyysit. }\end{array}$ & $\begin{array}{l}\text { Organisaation täy- } \\
\text { tyy voida varmistaa } \\
\text { datan laatu itse tai } \\
\text { antaa toisen osapuo- } \\
\text { len tehdä se. Korkea- } \\
\text { laatuinen data vaatii } \\
\text { aikaa ja rahaa. }\end{array}$ & $\begin{array}{l}\text { Hyvin tärkeä } \\
\text { Priorisointi: korkea }\end{array}$ & $\begin{array}{l}\text { On yhteydessä periaattee- } \\
\text { seen numero neljä. } \\
\text { Vaatii kirjaston ja tutkija- } \\
\text { yhteisön yhteistyötä. } \\
\text { Muiden toimijoiden tuot- } \\
\text { tama data ei usein ole } \\
\text { avointa ja läpinäkyvää. } \\
\text { Kirjastojen tulisi kerätä } \\
\text { dataa ja käyttötietoja se- } \\
\text { kä käyttää avoimen lähde- } \\
\text { koodin ohjelmia. }\end{array}$ \\
\hline
\end{tabular}




\begin{tabular}{|c|c|c|c|}
\hline $\begin{array}{l}\text { 6. Ota huomioon } \\
\text { tieteenalojen erot } \\
\text { julkaisemisessa } \\
\text { ja viittauskäytän- } \\
\text { nöissä. }\end{array}$ & $\begin{array}{l}\text { Tutkijoille tulee vali- } \\
\text { ta sarja mahdollisim- } \\
\text { man hyviä mittareita, } \\
\text { joista he voivat valita } \\
\text { itselleen sopivimmat. }\end{array}$ & $\begin{array}{l}\text { Hyvin tärkeä } \\
\text { Priorisointi: korkea }\end{array}$ & $\begin{array}{l}\begin{array}{l}\text { Normalisointi on monimut- } \\
\text { kaista ja vaikeaa. }\end{array} \\
\text { Nimittäjät tulee valita } \\
\text { huolella ja ne muuttuvat. } \\
\text { Kirjaston tulisi käyttää } \\
\text { useita datalähteitä. } \\
\begin{array}{l}\text { Kirjastojen tulisi tuntea } \\
\text { omalle yliopistolleen tär- } \\
\text { keät rankingit. }\end{array}\end{array}$ \\
\hline $\begin{array}{l}\text { 7. Perusta } \\
\text { yksittäisten } \\
\text { tutkijoiden } \\
\text { arviointi heidän } \\
\text { portfolionsa } \\
\text { laadulliseen } \\
\text { tarkasteluun. }\end{array}$ & $\begin{array}{l}\text { Kun tutkijoita verra- } \\
\text { taan toisiinsa, töihin } \\
\text { tulee tutustua. Tulee } \\
\text { huomioida osaami- } \\
\text { nen, kokemus, aktivi- } \\
\text { teetit ja vaikutus. }\end{array}$ & $\begin{array}{l}\text { Ei tärkeä kirjastoille, } \\
\text { hyvin tärkeä tutkijoille, } \\
\text { hallinnolle ja julkaisu- } \\
\text { rekisterin omistajille. } \\
\text { Priorisointi: matala }\end{array}$ & $\begin{array}{l}\text { Yhteydessä periaattee- } \\
\text { seen numero l. } \\
\text { Kirjaston ja tutkimushallin- } \\
\text { non yhteistyö tärkeää } \\
\text { Olennaisessa asemassa } \\
\text { ovat yksityisyyden suoja, } \\
\text { tutkimusaineistojen luot- } \\
\text { tamuksellisuus sekä ta- } \\
\text { voitteiden ja metodien } \\
\text { läpinäkyvyys. }\end{array}$ \\
\hline $\begin{array}{l}\text { 8. Vältä väärin } \\
\text { kohdistettua } \\
\text { konkretiaa ja } \\
\text { epäluotettavaa } \\
\text { tarkkuutta. }\end{array}$ & $\begin{array}{l}\text { Tulee käyttää monia } \\
\text { mittareita. Pitää vält- } \\
\text { tää liiallista tarkkuut- } \\
\text { ta ja ottaa huomioon } \\
\text { viittauslukujen satun- } \\
\text { nainen vaihtelevuus. }\end{array}$ & Hyvin tärkeä & $\begin{array}{l}\text { Periaatteen esiintuomat } \\
\text { ongelmat näkyvät erityi- } \\
\text { sesti silloin, kun käytetään } \\
\text { vain yhtä indikaattoria. } \\
\text { Tulee käyttää useita indi- } \\
\text { kaattoreita. } \\
\text { Kirjaston työntekijöiden } \\
\text { tulisi ymmärtää metriik- } \\
\text { kaa, dataa ja metodeita. } \\
\text { Indikaattorien ja arvioin- } \\
\text { nin mahdolliset muut ra- } \\
\text { joitteet tulee kertoa. }\end{array}$ \\
\hline $\begin{array}{l}\text { 9. Myännä } \\
\text { järiestelmään } \\
\text { kuuluvat arvioinnin } \\
\text { ja mittarien } \\
\text { seuraukset. }\end{array}$ & $\begin{array}{l}\text { Mittarit ohjaavat } \\
\text { julkaisemista ja toi- } \\
\text { mintaa. Tulee käyt- } \\
\text { tää useita mittareita } \\
\text { - yksittäiset mittarit } \\
\text { vääristävät }\end{array}$ & $\begin{array}{l}\text { Hyvin tärkeä } \\
\text { Priorisointi: korkea }\end{array}$ & $\begin{array}{l}\text { Vaara kasvaa mitä lähem- } \\
\text { mäs mennään henkiläkoh- } \\
\text { taista arviointia. } \\
\text { Tutkijoita ja tutkimus- } \\
\text { hallintoa tulee kouluttaa } \\
\text { metriikan vastuulliseen } \\
\text { käyttöön. }\end{array}$ \\
\hline $\begin{array}{l}\text { 10. Tutki ja } \\
\text { päivitä mittareita } \\
\text { säännöllisesti. }\end{array}$ & $\begin{array}{l}\text { Tutkimus ja arvioin- } \\
\text { ti muuttuvat. Mittarit } \\
\text { vanhenevat ja uusia } \\
\text { tulee tarjolle. }\end{array}$ & Hyvin tärkeä & $\begin{array}{l}\text { Kirjastojen tulee ymmär- } \\
\text { tää jatkuva ja äkkinäiset } \\
\text { muutokset } \\
\text { (tietokantojen muutokset } \\
\text { ja uudet toimijat, tilaajan } \\
\text { toiveet, uudet tilaukset). } \\
\text { Budjetointi ja resursointi. } \\
\text { Kirjaston tulee tarkkailla } \\
\text { metriikan ja skientometrii- } \\
\text { kan trendejä ja muutoksia. }\end{array}$ \\
\hline
\end{tabular}

Bibliometriikan tuoteseloste?

D ohjoismaisessa bibliometriikka-workshopissa Helsingissä marraskuussa 20I7, Heidi Hols Madsen, Lorna Elizabeth Wildgaard ja Marianne Gauffriau Kööpenhaminan yliopistosta kertoivat kehittäneens bibliometriikka-asiakkailleen consumer labelin eli "tuoteselosteen" Leidenin manifestista (Madsen, Wildgaard \& Gauffriau 2017).

Selosteen innoittajana oli kuluttajille ruoka-aineista ja -annoksista annettavat, pakkauksessa olevat selosteet tuotteiden ravinnearvoista. Bibliometrisessä tuoteselosteessa on lueteltu Leidenin manifestin periaatteet, ja niiden toteutuminen kyseisessä analyysissä on kuvattu nk. hymynaamoilla: vihreä hymyilee leveästi, keltaisen suu on suora viiva ja punaisella suupielet suuntaavat reilusti alaspäin.

Kööpenhaminalaiset kokeilivat selostetta kahdessa erilaisessa analyysis-

sä. Analyysin tehtyään he keskustelivat siitä, kuinka hyvin manifestin periaatteet täyttyivät ja tekivät selosteen, joka lähetettiin asiakkaalle. Tärkeä osa prosessia oli palaute, jonka asiakas antoi selosteesta. (Madsen, Wildgaard \& Gauffriau 2017.)

Ensimmäinen asiakas koki, että seloste oli ennemminkin ohjelistaus tai ammattisäännöstö analyysin tekijöil-

le kuin kuluttajansuojaa asiakkaalle. Hän oli kuitenkin tyytyväinen siihen, että seloste kiinnitti huomiota sääntöön kolme ("Ota huomioon, että paikallisesti merkittävä tutkimus voi olla

\section{Nutrition Facts}

Serving Size 4 oz (113g)

\section{Amount Per Serving}

Calories 360 Calories from Fat 140

$\%$ Daily Value ${ }^{*}$

Total Fat $16 \mathrm{~g} \quad \mathbf{2 4} \%$

Saturated Fat 9g Trans Fat $0.5 \mathrm{~g}$

\begin{tabular}{ll}
\hline Cholesterol $60 \mathrm{mg}$ & $\mathbf{2 0} \%$ \\
\hline
\end{tabular}

$17 \%$

\begin{tabular}{lll}
\hline Total Carbohydrate $51 \mathrm{~g}$ & $17 \%$ \\
\hline
\end{tabular}

Dietary Fiber $2 \mathrm{~g}$

\section{Sugars $23 \mathrm{~g}$}

Protein $5 g$

huippututkimusta"). Toinen asiakas ol hyvin kiinnostunut periaatteista ja koki niiden rikastavan analyysia. (Madsen, Wildgaard \& Gauffriau 2017.)

Madsen, Wildgaard ja Gauffriau toteavat, ettei manifesti sellaisenaan kelpaa tietoselosteena, vaan tarvitsee lisäselityksiä (Madsen, Wildgaard \& Gauffriau 2017).

Esityksessään tammikuussa 20I 8 pidetyssä \#respbib I 8-konferenssissa he miettivät, miten manifestia voisi päivittää ja huomioivat erityisesti kaksi asiaa: vastuunjaon painottamisen (kuka toimija vastaa mistäkin?) ja käsitteiden tulkinnan (Madsen, Wildgaard \& Gauffriau 2018). 


\begin{tabular}{|c|c|}
\hline Leiden Manifesto: Ten principles to guide quantitative research evaluation & Assessment \\
\hline $\begin{array}{l}\text { 1) Quantitative evaluation should support qualitative, expert assessment } \\
\text { The bibliometric analysis is included in a cV and publication track record in a research } \\
\text { application. The application will be evaluated by a panel of researchers from the health } \\
\text { sciences. }\end{array}$ & \\
\hline $\begin{array}{l}\text { 2) Measure performance against the research missions of the institution, group or } \\
\text { researcher } \\
\text { The indicators were not linked to an explicit research mission. According to the instructions } \\
\text { for applicants, bibliometric indicators are not mandatory but masy be included. No specific } \\
\text { indicators are mentioned. The overall evaluation criterion is scientific excellence. In the } \\
\text { health sciences, the h-index, number of publications and citations are offen presented in a } \\
\text { CV and may be seen as an implicitit standard for showing impact, and together with other } \\
\text { information indicate excellence. }\end{array}$ & \\
\hline $\begin{array}{l}\text { 3) Protect excellence in locally relevant research } \\
\text { Not relevant as the research area of Prof. NN and the application is international. }\end{array}$ & \\
\hline $\begin{array}{l}\text { 4) Keep data collection and analytical processes open, transparent and simple } \\
\text { The andlysis is developed in collaboration with Prof. NN and all indicators are known by the } \\
\text { health sciences research community. }\end{array}$ & \\
\hline $\begin{array}{l}\text { 5) Allow those evaluated to verify data and analysis } \\
\text { The analysis is verified by Prof. NN. }\end{array}$ & \\
\hline $\begin{array}{l}\text { 6) Account for variation by field in publication and citation practices } \\
\text { The analysis does not support comparisons with other research fields, e.g. by showing field- } \\
\text { norrmalized indicators ou including indicators offten used by other research fields. }\end{array}$ & \\
\hline $\begin{array}{l}\text { 7) Base assessment of individual researchers on a qualitative judgement of their } \\
\text { portfolio } \\
\text { See principle } 1 .\end{array}$ & \\
\hline $\begin{array}{l}\text { 8) Avoid misplaced concreteness and false precision } \\
\text { The analysis presents multiple indicators to give a pluralistic picture of Prof, NN's } \\
\text { performance. The data set for the analysis is developed in collaboration with Prof. NN to } \\
\text { ensure the best possible coverage. }\end{array}$ & \\
\hline $\begin{array}{l}\text { 9) Recognize the systemic effects of assessment and indicators } \\
\text { The analysis presents multiple indicators and not the } h \text {-index alone which is often seen in } \\
\text { health sciences. }\end{array}$ & \\
\hline $\begin{array}{l}\text { 10) Scrutinize indicators regularly and update them } \\
\text { See principle } 9 \text {. }\end{array}$ & \\
\hline
\end{tabular}

Lopuksi

Coombsin ja Petersin mukaan yliopisto- ja korkeakoulukirjastojen tulee panostaa bibliometriikkaan. Niiden kirjastojen, joilla ei vielä osaajia ole, tulee kouluttaa osaajia ja niiden, joilla osaamista jo on, pitää arvioida ja tarvittaessa uudistaa palveluitaan. Leidenin manifestin täysimittainen käyttöönotto kirjastoissa kannattaa, vaikka se on vaativaa, vie paljon aikaa ja voi tulla kalliiksi (Coombs \& Peters 2017, e.g. 324).

He suosittavat, etteivät kirjastot jää yksin, vaan tekevät yhteistyötä toisten kirjastojen kanssa tutkimuksen arvioinnin julkaisuanalyyseissä. Kirjastoalan tulisi yhdessä kehittää palveluita ja standardeja. (Coombs \& Peters 20I7, 335-336).

Bibliometrisiä analyysejä tekevissä kirjastoissa törmää joskus tilanteisiin, joissa pyydetään tekemään analyysejä, jotka eivät ole ohjeistusten ja suositusten mukaisia. Coombsin ja Petersin mukaan vastuullisen metriikan toteuttamisessa ja kysymyksissä kirjasto on avainasemassa (Coombs \& Peters 20 I7, 335). Kirjastoille on tärkeää keskustella bibliometriikan ja altmetriikan etiikasta ja käytännöistä tutkimushallinnon ja tiedeyhteisön kanssa. Keskustelun pohjana on hyvä käyttää kansainvälisiä suosituksia, kuten Leidenin manifestia ja DORAA (The Declaration on Research Assessment, https://sfdora.org/).

Yksi yritys keskusteluun oli 24.8.20 8 Helsingissä tutkimuspalvelupäivien ohessa Tutkimuksen tuen ja hallinnon verkoston (тUHA) järjestämä Vastuullisen metriikan kickoff -tilaisuus, jossa kuultiin mm. Tsv:n UNıFIlta saamasta vastuullisen metriikan kehittämistehtävästä ja pohdittiin yhdessä yliopistojen ja muiden tahojen asiantuntijoiden kanssa jatkotoimenpiteitä vastuullisen metriikan tietoisuuden edistämiseksi Suomessa.

\section{Tietoa kirjoittajista:}

JOHANNA LAHIKAINEN Johtava tietoasiantuntija Helsingin yliopiston kirjasto johanna.lahikainen@helsinki.fi

Anne Lehto
Johtaja
Vaasan yliopisto

Antтr Rousi Tietoasiantuntija Tiedekirjasto Tritonia, anne.lehto@tritonia.f Tutkimus- ja innovaatiopalvelut, Aalto-yliopisto antti.m.rousi@aalto.fi

\section{Lähteet:}

Coombs, S. K., Peters, I. (2017) "The Leiden Manifesto under review: what libraries can learn from it", Digital Library Perspectives, Vol. 33 Issue: 4, pp.324-338, https://doi.org/I0.I I08/DLP-OI-2017-0004

Hicks, D., Wouters, P., Waltman, L., De Rijcke, S., \& Rafols, I. (2015). Bibliometrics: The Leiden Manifesto for research metrics. Nature, 520 (7548), 429-43 I.

Löytyy myös verkkosivuilta: http://www.leidenmanifesto.org/

Madsen, H. H., Wildgaard, L. E., \& Gauffriau, M. (2017). Bottom-up Implementation of Leiden Manifesto.

Haettu sivulta

https://figshare.com/articles/Bottom-up_implementation_of_Leiden_

Manifesto/5624755, 2.7.20I8.

Madsen, H. H., Wildgaard, L. E., \& Gauffriau, M. (2018).

Leiden Manifesto as a Consumer Label.

Haettu sivulta

https://thebibliomagician.files.wordpress.com/201 8/03/leiden-manifesto-as -a-consumer-label-final.pdf 2.7.201 8

Picктоn, M. (2015). The Metric Tide: Are you using bibliometrics responsibly? Lainattu Coombsln \& Petersin kautta.

Haettu sivulta

https://researchsupporthub.northampton.ac.uk/2015/I 2/o9/the-metric -tide-are-you-using-bibliometrics-responsibly/ 5.9.2018.

Hicks, D. Wouters, P., Waltman,L., de Rijcke, S. \& Rafols, I. (2016 ) Leidenin tutkimusmetriikkamanifesti. Alkuperäisteos Hicks et al. (201 5) "Leiden Manifesto for Research Metrics", Nature, April 23, 201 5, http://www.leidenmanifesto.org/, http://www.nature.com/news/bibliometrics-the-leiden-manifesto-for-research -metrics-I.I735 I. Kääntänyt vuonna 2016 sYN:in tutkimuksen tuen verkoston ohjausryhmän piirissä Johanna Lahikainen. 